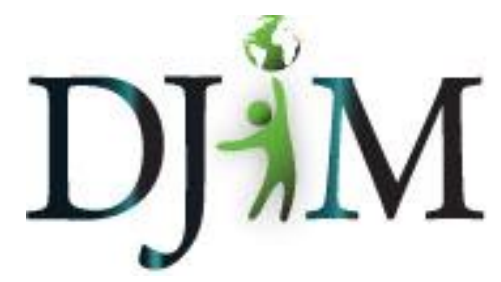

Volume7 - Spring 2011 djim.management.dal.ca

\title{
The Effect of Respect, Trust, and Fear in Adversarial Stakeholder Relationships: A Case Study on Water Commodification and Stakeholder Engagement
}

\section{Mark McGinley}

\begin{abstract}
Academic discussion around stakeholder engagement has been focused on the attributes of the various stakeholders rather than on the relationship between the stakeholders. This paper examines the role that intangible variables - respect, fear, and trust - play in stakeholder relationships that are characterized by intractable conflict. That role is explored through a case study of stakeholder groups with adversarial positions on the commodification and export of Canada's freshwater. Through discussion of the relationship between two sets of stakeholders with conflicting interests on Canada's freshwater commodification respect, fear, and trust are advanced as the key intangible variables that create the underlying conflict. With these root causes identified the paper explores methods to build respect, reduce fear, and establish trust among stakeholders in an effort to shift their relationship from primarily adversarial to collaborative in the hopes of facilitating constructive dialogue.
\end{abstract}

\footnotetext{
About the Author(s): Mark McGinley has received a Bachelors of Commerce from the University of Calgary, and is currently working towards completion of a Juris Doctor and Masters of Business Administration degrees from Dalhousie University. Mark is very interested in international law and trade and brings a unique legal perspective to this topic.
} 


\section{Introduction}

Conflict is the inevitable result of the intersection between multiple stakeholders with competing interests. Slowly, stakeholder engagement theorists are starting to realize the importance of examining the relationships between the stakeholders to ascertain, and dispel, that conflict. Historically, academic discourse on stakeholder engagement has been focused on attributes of the organizations or stakeholders rather than on the attributes of the relationship between the stakeholders (Frooman, 1999). When stakeholder relationships have been examined, the examination is typically limited to largely supportive and collaborative relationships (Bourassa \& Cunningham, 2010; Noland \& Phillips, 2010).

This paper seeks to build on the emerging body of work on stakeholder engagement by analyzing adversarial stakeholder relationships, relationships defined by intractable conflict. When stakeholders are locked in an intractable conflict, shifting the analysis from examination of the stakeholder's attributes to analysis of the stakeholder's relationships yields novel insights, and gives a more accurate depiction of the true source of the conflict therein. To conduct this analysis three intangible variables have been identified that underlie the conflict inherent in the relationship between adversarial stakeholders: fear, trust, and respect.

\section{Background}

To demonstrate the effect that these intangible variables have on stakeholder conflict, this paper will examine the nature of the relationship between two sets of stakeholders in relation to their respective interests in the commodification of Canada's fresh water. Despite the substantial amount of discussion between the stakeholders on this issue, little official progress has been made in finding a long-term solution. This lack of progress can be attributed to the complexity of the problem, the multiple conflicting interests of the stakeholders involved, and the adversarial nature of the relationships between these stakeholder groups. For examples of some of the stakeholders affected by the commodification of water see the figure 1 . on page 3 .

With such a diverse group of stakeholders, competing interests are inevitable and it can be difficult, if not impossible, to achieve stakeholder alignment. Conflict can arise not only between the stakeholder groups, but also within the groups themselves, further complicating efforts at stakeholder alignment (Bourassa \& Cunningham, 2010). Additionally, in some cases stakeholders are not interested in constructive engagement, and are unwilling to cooperate to arrive at a solution (Bourassa \& Cunningham 2010). The success or failure to engage stakeholders is primarily attributed to an organization's ability to respect their stakeholders, to address the fear arising from the power imbalances between the stakeholder groups, and the degree to which they can facilitate trust between the groups (Bourassa \& Cunningham, 2010). 
Figure 1:

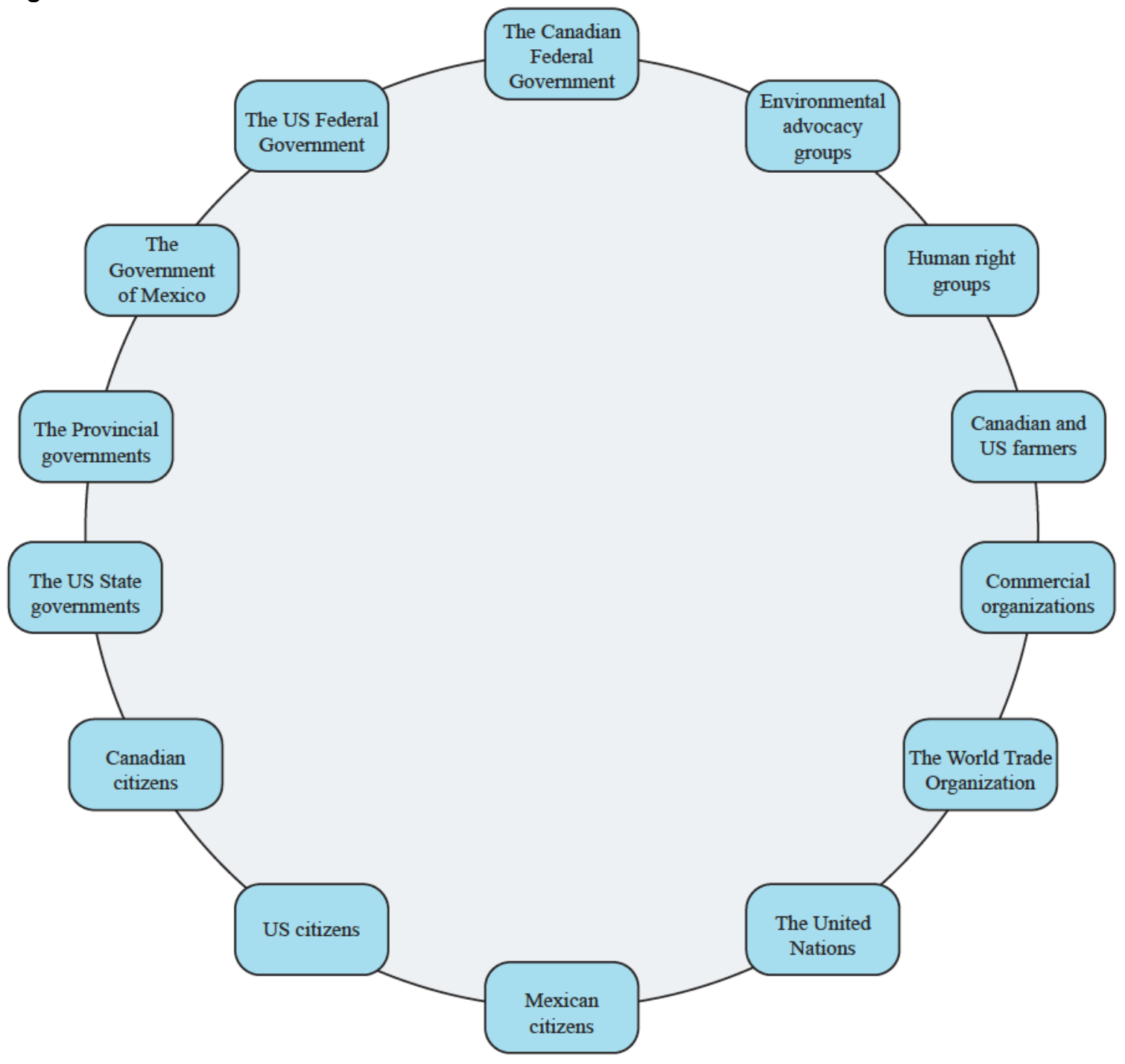

By analyzing the effect of fear, trust, and respect on the relationships between these stakeholders, we can identify and hopefully eliminate the roadblocks that are preventing these stakeholders from engaging in constructive dialogue

\section{Methodology}

The analytical approach utilized in this paper is comprised of a literature review pertaining to stakeholder theory, stakeholder engagement theory, and the commodification of water. Exploration of the topic will be conducted through two case studies focused on two sets of stakeholder groups with conflicting positions on the commodification of water.

The main weakness of this paper stems from the difficulty in applying stakeholder theory to governments. Some have argued that "stakeholder" is not synonymous with "citizen", and that a much stronger relationship between an organization and its constituency group is required 
for stakeholder status (Phillips, Freeman \& Wicks, 2003). Others have favored expansion of stakeholder theory to governments, most notably former British Labour Party Leader Tony Blair who coined the term "Stakeholder Economy" in a 1996 speech (Blair, 1996). The drawback of expanding stakeholder theory to government is the dilution of the theory's value that results from it; the idea being that if everyone is a stakeholder, the term loses all meaning. However, even critics of this expansion recognize its necessity:

However, for stakeholder theory to truly come into its own as a theory of strategic management and organization ethics, it will need to be applied to more than just the large, publicly held corporation. (Phillips et al., 2003, p. 480)

This paper is not arguing for an expansion of stakeholder theory to government. The use of governments in the case studies merely serves to illustrate the effect of intangible variables on the relationships between stakeholder groups. In this sense, the government bodies identified in the cases are best defined an aggregation of individual stakeholders and stakeholder groups.

Given the extensive number of stakeholders affected by this issue, it is necessary to limit the scope of this paper to analysis of the relationships between two sets of stakeholder groups. Through this limitation, a more in-depth analysis can be conducted, and more meaningful results gleaned from it. Despite the limited scope of this paper, I am confident that the analysis can be extrapolated to the other stakeholders identified, and to other complex issues where multiple stakeholder groups have adversarial positions created by the intangible emotions of fear, trust, and respect.

\section{Water commodification}

A commodity is defined as "something that is useful or valued" (Merriam-Webster, n.d.), and the commodification of water refers to the creation of a market where freshwater, sourced from rivers, lakes, or inland basins, is bought and sold by interested parties at market prices. The idea of water as a tradable commodity is not a new one; water is being traded in numerous areas of the world and its commodification is currently being examined and implemented by the United Kingdom and Australia (Turner, 2004).

\section{The world's increasing water scarcity}

Water is one of the world's most important, and most valuable, natural resources. It is heavily utilized in agriculture and manufacturing, and it is a necessary requirement for human life (The Economist, 2010). Canada is a water rich nation, holding $6.5 \%$ of the world's renewable water resources while housing only $0.5 \%$ of its population (Bakenova, 2008). With such a small population relative to the size of our freshwater holdings, Canada ranks third out of the world's countries in water abundance (Bakenova, 2008). Given the wealth of our supply, and the relative scarcity of the resource, it is no surprise that discussions about the commodification of Canada's freshwater have made national headlines (Francis, 2010). 
Currently, $8 \%$ of the world's population lives in countries chronically short on water, and that number is forecasted to increase to $45 \%$ by 2045 (The Economist, 2010). Not only does chronic water scarcity mean that people are going thirsty, but also that they lack the ability to grow food, further exacerbating the effect of insufficient water supply on their health. Climate change is also expected to increase water scarcity, intensifying the need to find a solution to the forecasted worldwide demand for water (Olszynski, 2006). Proponents of water commodification advance it as a long-term solution to the problem of increasing water scarcity (The Economist, 2010).

\section{Canada's history with water's commodification and export}

Canadians have a complicated and emotional history with the concept of water as a commodity and with any removal of Canada's freshwater-especially by the Americans.

A reflexive "aqua-nationalism," clothed in environmental righteousness, is hostile to any suggestion that Canada's water could ever become a tradable commodity. The animus is all the more implacable if the discussion involves trading water with Americans-an idea close to treason in some eyes. (Wood, 2008, p. 1)

In 1901, Americans, concerned with the possibility of a water shortage, constructed a $46 \mathrm{~km}$ long canal from the St. Mary River to the Milk River, which ran between Alberta and Montana (Lasserre, 2006). Outraged, in 1903 Albertans fought back, designing a canal to recapture the water (Wood, 2008). This prompted the US and Canadian governments involvement in the situation, and led to the signing of the International Boundary Waters Treaty. This treaty is still in place today, and with it the establishment of the International Joint Commission, charged with settling any inter-boundary water disputes (Wood, 2008).

Since the Milk River incident, Canadians and Americans have made several attempts to create canals and pipelines to bring water from Canada to the US (Lasserre, 2006). One example, a canal designed in 1959 by Canadian Engineer Tom Kieras, would have required six nuclear power plants merely to pump the water from James Bay to Georgian Bay in Lake Huron (Lasserre, 2006). As capital costs for the Canal's construction were enormous, and the demand insufficient to justify the expense, the project was abandoned (Lasserre, 2006). The demand for massive water diversions from Canada to the US has remained low since the abandonment of this project, mainly due to increased water conservation reducing demand in the US (Wood, 2008). However, this détente will likely not endure due to the current, and forecasted, effects of climate change.

So serious is the possibility that climate change could affect Canada's water quality and quantity, that Environment Canada is spending millions of dollars to assess the risk (Lasserre, 2006). The effects of climate change are already taking a toll; less snow falls in the Prairies in the winter and it melts earlier in the spring. Further, widespread evidence shows a major retreat of small alpine and continental glaciers in response to twentieth century warming (Environment Canada, 2004). Indeed, historical data suggests that the larger downstream flow volumes produced by increased melting caused by warmer temperatures have already passed, and that basins have entered a potentially long-term trend of declining flows (Lasserre, 2006). 
Unfortunately, but not surprisingly, this trend is not confined to Canada. The US is also feeling the affects of climate change, with similar conclusions having already been drawn regarding the impact of the Rockies' disappearing snow and glacial cover in the Western US (Gleick, 2000). Environment Canada has acknowledged this as having the potential to shift US demand for water export from Canada.

....In the longer term, however, a potential market such as the American southwest may exhaust some of the more easily applied local alternatives and begin to look more seriously to Canada for relief. Climate warming, of course, could hasten that eventuality. (Environment Canada, 2004, p. 6)

Having reviewed the issues surrounding water commodification, it is useful to examine the literature pertaining to stakeholder theory, and stakeholder engagement theory, to provide a foundation for discussion around the effect of the intangible variables on adversarial stakeholder relationships.

\section{Stakeholder Theory}

Stakeholder theory is defined as a theory of organizational management and ethics (Phillips et al., 2003). The value of stakeholder theory derives from its unique focus on morals and values as a central feature of managing organizations (Phillips et al., 2003).

Stakeholder theory stems from the differentiation between stakeholders and shareholders. Shareholders are people who own shares of stock in a publicly traded company, making them part owners of that company (Businessdictionary.com, n.d.). As owners, managers have a legal and fiduciary duty to act in their best interests, and to maximize the value of the organization (Boatright, 1994). Conversely, a stakeholder is someone who has a "stake" in the organization, i.e. is affected directly or indirectly by the organization's actions, and is not simply an owner in the company (de Bakker \& den Hond, 2008).

Stakeholders are categorized into two main groups: primary stakeholders and secondary stakeholders. Primary stakeholders are people that have direct ties to the organization, e.g. employees or customers. Secondary stakeholders "are diverse and include those who are not directly engaged in the organization's economic activities but are able to exert influence or are affected by the organization" (Savage, Nix, Whitehead, \& Blair, 1991, p. 9).

Noting the difference between shareholders and stakeholders, it could be argued that stakeholder theory, which advances the notion that managers should take into consideration the interest of stakeholders and the effect of the organization's action on them, is incongruent with the legal duty managers have to maximize the value of the organization for shareholders. Further, the problem is compounded by the difficulty in finding an objective definition for value". Maximizing the organization's value for all stakeholders may not maximize the value of the share price, a common method of objectively assessing the value of publicly traded corporations. Despite the debate around this issue, theorists posit that the point is largely moot, noting that "managing for stakeholders is, in fact, the most effective way to run a 
business for all stakeholders, including shareholders" [italics in original] (Phillips et al., 2003, p. 496). Moving from stakeholder theory, which is primarily concerned with the distribution of financial outputs of the organization to stakeholders (Phillips et al., 2003), we must turn to stakeholder engagement theory to examine the interactions between stakeholders and organizations.

\section{Stakeholder engagement theory}

Stakeholder engagement theory is best understood as the practices undertaken by organizations to positively involve stakeholders in organizational activities (Greenwood, 2007). Given the fairly broad definition of the theory offered, stakeholder engagement can be interpreted in a correspondingly broad fashion. It has been noted that stakeholder engagement is an under-theorized area (Greenwood, 2007), with focus on the attributes of either the stakeholders or the organization, rather than on the attributes of the relationship between them (Frooman, 1999).

The discussion by stakeholder engagement theorists is also focused on the moral aspect of stakeholder engagement. Questions pertaining to who should get what, and in what manner and quantity are poised at organizations in assessment of the moral righteousness of their actions. Recent literature advances the notion that stakeholder engagement is, for the most part, a morally neutral practice (Greenwood, 2007), with the morality of stakeholder engagement derived solely from an organization's use of the theory.

\section{The roles fear, trust, and respect play stakeholder engagement}

The organizational field in which firms operate is broad and complex, comprised of highly diverse stakeholders representing conflicting agendas and opposing interests (Bourassa \& Cunningham, 2010). As it is futile to attempt an alignment of the positions of these stakeholders, the question then becomes, how does an organization effectively balance the needs and wants of various stakeholders with conflicting interests?

Stakeholder interests are most effectively balanced by respecting the diversity of stakeholder opinions (Bourassa \& Cunningham, 2010), seeking to build and facilitate trust (Coleman, Fisher-Yoshida, Stover, Hacking, \& Bartoli, 2008 a), and reducing the stakeholders' fears (Coleman, Fisher-Yoshida, Stover, Hacking, \& Nowak, 2008 b). Each of the intangible variables, respect, trust, and fear, are briefly outlined below.

\section{Respect:}

Respect has been identified as a prerequisite for the development of trust and the formation of constructive relationships. Development of these relationships is critical if the organization wants to engage stakeholders in a participatory fashion (Bourassa \& Cunningham, 2010). Respect is best demonstrated by communicating to stakeholders that their views are valued and merit consideration, thus ensuring that the stakeholders that their views are valued and merit consideration, thus ensuring that the stakeholder feels that their views have been heard (Bourassa \& Cunningham, 2010). 


\section{Trust:}

Trust helps to facilitate constructive dialogue and strengthens stakeholder relationships (Coleman, $2008 \mathrm{~b}$ ). Trust has been shown to diminish conflict between parties and improve working relationships, thus enhancing the support that parties offer each other and improving the performance of their relationship (Khodarahmi, 2009). Trust can be developed by demonstrating fairness and equal treatment of stakeholders. Additionally, an organization's authentic demonstration of honesty and caring has been shown to develop trust (Coleman, 2008 b).

\section{Fear:}

Fear can be terribly powerful in situations where stakeholders have conflicting interests; the fear of further loss, violence, or reprisal for participating in dialogue has a negative effect on the stakeholders' relationships and is one of the primary obstacles to constructive dialogue (Coleman, 2008 b). A successful method that has been employed to reduce stakeholder fears is the recruitment of allies in the relationship building process, which demonstrates the ability to find some common ground (Coleman, $2008 \mathrm{~b}$ ).

There are many types of fear that affect stakeholder engagement, especially in the context of water commodification. The Canadian and US governments fear loss of support from their constituents, loss of the mutually advantageous relationship that they share, a fear of embarrassment on the world stage and the consequences that may follow from that, a loss of sovereignty and national security, and the possibility of not being able to provide an adequate supply of water for their citizens. These fears will be further analyzed in the cases to follow.

Having described the three main intangible variables that serve as the source of the underlying conflict in stakeholder relationships, analysis of the case studies demonstrating the effect of respect, trust, and fear on stakeholder relationships will now be conducted, and recommendations to improve stakeholder alignment offered.

\section{Case 1: The Canadian Government vs. The US Government}

\section{Nature of the relationship between the stakeholders}

The commodification of water is a contentious issue between the Canadian and US Governments for a myriad of reasons. Both governments have been elected to represent the interests of their constituents. However, the problem is that the interests of each nation's constituents lack homogeneity. Some citizens are in favour of the commodification of water, while others strongly oppose it.

These positions are adopted on the basis of a number of different grounds. Some citizens approve of the commodification of water on the grounds that it will bring revenue into their provinces, others approve of it thinking that it will further strengthen the relationship between Canada and the US. Conversely, some citizens oppose water commodification and subsequent export out of concerns relating to the environmental impact it would have. Moreover, they are concerned about the potential loss of Canada's sovereignty, and the possibility that Canada could suffer water shortages if water export were to begin. The 
complication of the issue is further exacerbated by the existence of free trade agreements in place between the two countries, most notably the North American Free Trade Agreement (NAFTA). By examining the Canadian and US Governments' respective attitudes towards water commodification, and how they are shaped by the intangible variables, the issues preventing constructive dialogue on this issue can be identified and hopefully eliminated.

In 2002, the Canadian Government, ceding to the wishes of Canadians that water not be commoditized, amended the International Boundary Waters Trading Act to prohibit the bulk removal of fresh water (consisting of all water contained in rivers, streams, lakes, and basins) for any purpose, including export (Bakenova, 2008). A diverse number of arguments were put forward to the Canadian Government to prevent the commodification of water, most notably by the Council of Canadians (COC), which is considered a left wing lobby group. The main argument advanced by this organization was that water commodification posed a threat to national security. The COC argued that by allowing Canadian water to be exported, we would face a reduction in sovereignty, and a corresponding decrease in our national security. The COC's tactics amounted to little more than fear mongering, demonstrated by the following quote: "They're coming to take our water...right now. Canada's water-our water-is under terrible threat" (The Council of Canadians, 2007, p. 1).

Additionally, the COC also argued that if Canada were to begin to export water they would be legally obligated to continue, as Chapter 11 of NAFTA requires that once something becomes a tradable good it must remain a tradable good (Szydlowski, 2007). Obfuscating this issue further is the fact that a "tradable good" is not formally defined in the General Agreement on Tariffs and Trade (GATT), which serves as the source for all of NAFTA's definitions (Matsuoka, 2001). Although "tradable good" is not formally defined, water's status as a tradable good can be inferred from GATT's definition of a "primary product". A primary product is defined as "any product of farm, forest or fishing or any mineral, in its natural form or which has undergone some processing as is customarily required to prepare it for marketing in substantial volume in international trade" (General Agreement on Tariffs and Trade, 1947, p. 7). The process by which water would be processed, i.e. piped or diverted by way of canal, would likely make water a primary product, and thus a tradable good.

Conversely, the US Government is seeking the commodification of Canada's water, and is hoping to gain the ability to import bulk water from Canada. The US has very different perceptions about water ownership than Canada, and has an entirely different legal structure for allocating water ownership rights (Ziff, 2006). Specifically, in the Western US, you can hold legal title to water reserves, allowing you to sell it like any other natural resource (Kwasniak \& Hursh, 2009). This is contrasted with Canada's riparian water rights, which allow only for the use, and not sale, of the water subject to conditions (Ziff, 2006). Precedent further builds on the US Government's belief that water should be commoditized, as the US is already importing bulk water from Mexico via the Rio Grande for use in agriculture (Szydlowski, 2007). Adding to both the necessity and urgency of the US Government's position that Canada should allow bulk water exports is the mid-West's growing water scarcity (Szydlowski, 2007). All of the above contribute to the US Government's strong position on Canada allowing water commodification, and Canadian bulk water export. 


\section{Effect of respect, fear, and trust on the relationship}

The adversarial nature of the Canadian and US Governments' conflicting positions on water commodification can best be explained through the effect of fear on their relationship. Canada and the US comprise an extremely important coalition, mutually advantageous to both countries economically and politically. There is, however, a large power imbalance between the two nations stemming from Canada's significantly smaller population and limited international influence (Fox \& Hero, 1974). This power imbalance helps to explain the differences in positions between these stakeholders, and fuels the fear preventing constructive dialogue.

The Canadian Government is afraid of losing control of one of its most valuable natural resources if it begins exportation through the provisions contained in NAFTA, while also fearing loss of the resource itself as climate change may decrease Canada's fresh water reserves. Moreover, the Canadian Government is concerned with possible retaliatory action from the US Government if it refuses to acquiesce to US pressure. The US Government fears the potentially catastrophic consequences of a water shortage on its cities and agricultural operations. Additionally, both governments fear damaging the long and mutually advantageous relationship they share. These fears are the underlying cause that is preventing these governments from progressing towards a solution on water commodification.

\section{Recommendations to improve stakeholder alignment}

This fear can be dispelled by educating each country's citizens on the realities of NAFTA, and by providing assurances regarding the preservation of Canadian sovereignty. The fact is that even if Canada did begin bulk water exports there are several provisions in NAFTA pertaining to environmental impact, and "public morals" that could effectively allow Canada to restrict its water exportation once begun (Szydlowski, 2007). Regarding national security, however, Canada's fears are well founded. As far back as 1971, a senior advisor to then President Nixon was quoted as saying, "The bargaining over Canadian water has started a cold war in resources that Canada can only lose" (Bakenova, 2008, p. 683). By reassuring Canadians of the continuation of their national sovereignty, possibly through the use of bilateral treaties, the US can dispel Canada's fear surrounding water commodification.

Additionally, The US could bring the Government of Mexico to the negotiation table. As an ally of both countries, and a current exporter of freshwater to the US, Mexico could help allay Canada's fears regarding loss of sovereignty. This, together with an educational campaign informing Canadians of the exemptions and limitations of NAFTA, would allow the Canadian and US Governments to proceed with honest discourse on water commodification, and shift the stakeholders' positions from adversarial to collaborative. 


\section{Case 2: The Canadian Federal Government vs. The Canadian Provincial and Territorial Governments}

\section{Nature of the relationship between the stakeholders}

There are a number of issues at play between the Canadian Federal, territorial, and provincial governments (hereinafter, the term provincial governments is used to refer to all of the provincial and territorial governments) that are preventing constructive discussion regarding the commodification of water.

Currently, uncertainty exists regarding the extent of the rights conferred by the constitution on the Federal and provincial governments' water ownership rights; specifically, the extent of the alienability of the provinces' water rights (Bakenova, 2008). There is further conflict between the Federal and Provincial governments centered on the provincial governments' desires to realize the economic gains associated with water export, and the Federal Government's desire to maintain national security.

One of the main sources of conflict between the Federal and provincial governments stems from the uncertainty regarding the powers conferred on these two governments by the Constitution Act, 1867 (Bakenova, 2008). Sections 91 and 92 of The Constitution delineate the division of powers, with section 91 laying out the Federal powers and section 92 laying out matters falling within provincial purview (The Constitution Act, 1982). Section 92 confers on the provinces control over their natural resources, including water within their boundaries and inland waters (The Constitution Act, 1982). This gives the provinces total control over their resources; however, this is subject to the powers conferred on the Federal Government in section 91 .

Section 91 gives the Federal Government control of navigation and shipping, and the regulation of trade and commerce (The Constitution Act, 1982). Section 91 could be interpreted to give the Federal Government the power to prevent the provinces from exporting water to the US, as that would constitute international trade. Additionally, the Federal Government has a residual power allowing them to make laws for the "peace, order, and good Government of Canada" (The Constitution Act, 1982). This residual power could allow the Federal Government to step in and regulate provincial water ownership if they felt that water export could jeopardize national security (Bakenova, 2008). As a result of these conflicting and overlapping jurisdictional issues, any kind of water export agreement would likely require the consent of both the Federal and provincial governments, though it is still unclear whether a province could unilaterally initiate water export without the consent of the Federal Government (Bakenova, 2008).

If a province was to unilaterally initiate fresh water export there are some who question Ottawa's political will to challenge it, stating that it would take a lot of fortitude in today's political climate to take a provincial government to court over constitutional rights. Some have contended that the Federal Government, "[h]as demonstrated neither the capacity nor the interest" for such a fight (Bakenova, 2008, p. 697). However, there is a long history of Ottawa taking the provinces to court, and vice versa, on a host of issues to establish rights and clarify 
authority under section 91 and 92 (Ryder, 1991). Given the gravity of the issue, and the nature of the interests affected, it is likely that the Federal Government would take whichever provincial government first tried to export water to court, if only to formally clarify the nature of the rights conferred by the Constitution.

Aside from the constitutional issues, a major concern for the Federal Government is that the fight over water commodification, if handled the wrong way, would lead to increased decentralization of Canada. The relationship between the Federal and provincial governments could be construed as tense, and fighting a battle over who has ownership of water rights might serve to deepen the divide between Ottawa and the provinces. However, if the Federal Government were to take a more collaborative approach with the provinces wishing to export water, through usage of the principles of asymmetrical federalism, this issue could serve to bring the Federal and provincial governments closer together.

Asymmetrical federalism refers to the notion that different constituents of a federation have asymmetrical, or uneven, powers (Brock, 2001). This idea could powerfully affect the resolution of this conflict as not all of the provinces will have the capability or desire to be involved in water export. This would allow the Federal Government to craft deals with the individual provinces that want to export water. This would create asymmetry in the powers of the provincial governments, as some would be allowed to export water and others would not, but the effect would be inconsequential as the provinces that cannot export water could not, or would not, want to. Indeed, "asymmetrical treatment of the various units of a federation are the lubricant of the machinery that keeps the nation rolling along" (Brock, 2008, p. 144), and similar deals have already been struck, most notably with Québec's language rights (Brock, 2008).

There is some debate as to whether some of the provinces are already engaged in water export- weakening the validity of any future attempt by the Federal Government at restriction. The Provincial Governments of Ontario and British Columbia already export millions of liters of bottled of water each year to the US for consumption (Szydlowski, 2007). To date, the Federal Government has avoided the application of NAFTA by drawing a distinction between bottled water and bulk freshwater exports (Szydlowski, 2007). However, the provincial governments, after seeing the potential for revenue from bulk water exports, may reject this distinction as being merely semantic. Experts estimate that one pipeline carrying freshwater from Manitoba to Texas could double annual revenue for provincial and municipal governments (Francis, 2010). They also predict that bulk water exports will begin to take place from British Columbia, Manitoba, Newfoundland and Labrador, and Québec within a handful of years (Francis, 2010). If the Federal Government continues to oppose major provincial windfalls in this area, the gap between the Federal and provincial governments could widen, with deleterious effects on numerous other public issues from health care to education.

\section{Effect of respect, fear, and trust on the relationship}

The conflict apparent in the relationship between the Federal and provincial governments is best explained through the provincial governments' perception that the Federal Government does not respect their constitutional rights. This perception is exacerbated by the provinces' 
distrust of the Federal Government. The level of distrust between the Federal and provincial governments is palpable, and stems from a long history of non-consensual decision making with the Federal Government making decisions in the face of opposition from some of the provincial governments, illustrated in this case by the enactment of the Canadian Charter of Rights and Freedoms.

The enactment of the Canadian Charter of Rights and Freedoms was a highly contentious issue, with the provinces fearing that it would strip provincial autonomy. The Charter was only saved by the last minute inclusion of the section 33 notwithstanding clause, which allows provincial governments to enact legislation free from Charter scrutiny for renewable five-year terms (Whyte \& Romanow, 1984).

This distrust is further evidenced by the Federal Government's failed implementation of the 1999 Canada Accord for the Prohibition of Bulk Water Removal from Drainage Basins Act (Bakenova, 2008). This enactment called for a complete ban on all bulk water exports from Canada, including export by way of pipeline. It was developed after substantial scientific research examining the environmental impact of bulk water export, such research having been sponsored by the Federal Government (Bakenova, 2008). Although all of the provinces agreed to the Act, only nine would ratify it, with Alberta, British Columbia, Manitoba, and Saskatchewan all reserving their position on the issue pending further research and consultation (Bakenova, 2008).

The fact that some of the provincial governments felt the need to have their own studies conducted demonstrates their distrust in the Federal Government. The Canada Accord for the Prohibition of Bulk Water Removal from Drainage Basins Act is an illustration of the Federal Government trying to impose a unilateral solution for the water commodification, the Act having been developed solely on the initiative of the Federal Government, and without any input from the provincial governments. The provinces were merely asked to endorse the legislation as a fait accompli (Bakenova, 2008). The notion of developing a piece of legislation designed to curtail the constitutional rights of the provincial governments without consulting them is baffling, and further contributes to the Federal Government's perceived lack of respect for the provincial governments.

\section{Recommendations to improve stakeholder alignment}

By addressing the provincial governments' perception that the Federal Government lacks respect for provincial power, the obstacles preventing productive dialogue between these two stakeholders can begin to dissipate. Rebuilding the trust between these two groups will take time, and sincere, authentic effort on the part of both parties. The Federal Government, acknowledging the futility of trying to impose a unilateral solution on the provinces, should embrace the principles of asymmetrical federalism and work with the individual provinces seeking to export water. The Federal Government must then work with those individual provinces seeking to create a deal that would allow them to do so, subject to restrictions for the benefit of the environment, and for Canada generally. 
Through this process of collaboration, the provinces will feel respected, as the Federal Government would be demonstrating the will to work with them individually, as opposed to imposing a "one size fits all" solution on them. Through working together, the systemic distrust between these two stakeholders may be diminished. Such cooperation would prevent the further decentralization of Canada, while improving the climate for negotiation on a host of other interprovincial matters including education and health care. By implementing these strategies, the provinces' perceptions regarding the Federal Government's lack of respect can be addressed, and the systemic distrust diminished, moving the stakeholders from an adversarial to a collaborative relationship.

\section{Conclusion}

Commodification of Canada's freshwater would affect a multitude of individual stakeholders and stakeholder groups. The individual stakeholders and stakeholder groups would be affected positively and negatively by the commodification of water in a myriad of ways. Some would see positive benefits of water commodification in increased provincial revenues, and in the case of commercial organizations personal revenues. Jobs would be created, as water export would necessitate large-scale construction to bring down cost through increased economies of scale. Others would be negatively affected, perhaps even just emotionally. It is difficult to quantify the fear that some would feel towards water commodification's effect on the environment and national security; should these fears materialize, the quantification would, unfortunately, be much easier.

These individual stakeholders and stakeholder groups have wide ranging interests that often come into direct conflict with the interests of other stakeholders and even with themselves as a stakeholder could want to realize the economic gain associated with water commodification, yet be opposed to any environmental impact. Their positions include, but are not limited to the promotion of free trade, concern for the environment, preservation of national security, provincial independence, national unity, desire to make economic profits, desire to protect national resources, and fear of damaging strategic relationships.

Through analysis of the above cases it becomes apparent that the root cause for the conflict in these stakeholder relationships stems from a combination of lack of respect, fear, or distrust. By identifying the root cause, stakeholders can then begin working towards eliminating the true cause of the conflict. Through elimination of the conflict, stakeholders can shift the their relationship from adversarial to collaborative, facilitating constructive dialogue, and helping to move them towards finding a solution. 


\section{References}

Bakenova, S. (2008). Interpreting the emergence of water export policy in Canada. Southeastern Political Review, 36(4), 676-719.

Blair, T. (Performer). (1996, January 19). Tony Blair explaining stakeholder economy [Radio series episode]. British Broadcasting Corporation, London.

Boatright, J. (1994). Fiduciary duties and the shareholder-management relation: Or, what's so special about shareholders. Business Ethics Quarterly, 4(4), 393-407.

Bourassa, M. A. \& Cunningham, P. H. (2010). Engaging, balancing, bridging: Understanding the complexity of stakeholder engagement. Unpublished manuscript.

Brock, K. (2008). The politics of asymmetrical federalism: Reconsidering the role and responsibilities of Ottawa. Canadian Public Policy / Analyse de Politiques, 34(2), 143-161.

Businessdictionary.com. (n.d.). Shareholder. Retrieved from http://www.businessdictionary.com/definition/shareholder.html

Coleman, P. T., Fisher-Yoshida, B., Stover, M. A., Hacking, A. G., \& Bartoli, A. (2008a). Reconstructing ripeness 2: Models and methods for fostering constructive stakeholder engagement across protracted divides. Conflict Resolution Quarterly, 26(1), 42-69.

Coleman, P. T., Fisher-Yoshida, B., Stover, M. A., Hacking, A. G., \& Nowak, A. (2008b). Reconstructing ripeness 1: A study of constructive engagement in protracted social conflicts. Conflict Resolution Quarterly, 26(1), 1-42.

de Bakker, F. \& den Hond, F. (2008). Introducing the politics of stakeholder influence: a review essay. Business Society, 47(1), 8-20.

Environment Canada, National Water Research Institute. (2004). Threats to water availability in Canada. Burlington, Ontario: En40-237/3-2004E.

Fox, A. B., \& Hero, A. O. (1974). Canada and the United States: Their binding frontier. International Organization, 28(04), 999-1014.

Francis, D. (2010). Why water is becoming the new oil. Retrieved from http://www.financialpost.com/scripts/story.html?id=4b015243-8ded-409f-bddcd1cb8924a0ff\&k=75194

Frooman, J. (1999). Stakeholder influence strategies. Academy of Management Review, 24(2), 191-205.

General Agreement on Tariffs and Trade. (1947, Oct 30). Retrieved from http://www.wto.org/english/docs_e/legal_e/gatt47_e.pdf 
Gleick, P. (2000). Water: the potential consequences of climate variability and change for the water resources for the United States. Pacific Institute for Studies in Development, Environment, and Security. Oakland, CA.

Greenwood, M. (2007). Stakeholder engagement: Beyond the myth of corporate responsibility. Journal of Business Ethics, 74, 315-327.

Khodarahmi, E. (2009). Strategic public relations. Disaster Prevention and Management, 18(5), 529-534.

Kwasniak, A. J. \& Hursh, D. R. (2009). Right to rainwater-- a cloudy issue. Review of Legal and Social Issues, 26(106), 1-24.

Lasserre, F. (2007). Managing water diversion from Canada to the United States. International Journal, 62, 81-92.

Matsuoka, K. (2001). Tradable water in GATT/WTO law: Need for new legal frameworks? Proceedings of the Globalization and water resources management: The changing value of water (pp. 1-7).

Merriam-Webster. (n.d.). Commodity. Merriam-Webster. Retrieved February 20, 2011, from http://www.merriam-webster.com/dictionary/commodity

Noland, J. \& Phillips, R. (2010). Stakeholder engagement, discourse ethics and strategic management. International Journal of Management Reviews, 12(1), 39-49.

Phillips, R., Freeman, R., \& Wicks, A. (2003). What stakeholder theory is not. Business Ethics Quarterly, 13(4), 479-502.

Olszynski, M. Z. P. (2006). The commodification of Canadian water: Exploring international trade implications. Saskatchewan Law Review, 69, 221-249.

Ryder, B. (1991). The demise and rise of the classical paradigm in Canadian federalism: Promoting autonomy for the provinces and the first nations. McGill Law Journal, 36, 308-412.

Savage, G., Nix, T., Whitehead, C., \& Blair, J. (1991). Strategies for assessing and managing stakeholders. Academy of Management Executive, 5(2), 61-75.

Szydlowski, G. F. (2007). The commoditization of water: A look at Canadian bulk water exports, the Texas water dispute, and the ongoing battle under NAFTA for control of water resources. The Colorado Journal of International Environmental Law and Policy, 18(665), 666-700. 
The Canadian Department of Justice. (1082). The Constitution Act. Retrieved from http://laws.justice.gc.ca/en/const/1.html

The Council of Canadians. (2007). Backgrounder: The North American future 2025 project: The council of Canadians' analysis. Retrieved from http://www.canadians.org/water/documents/NA_Future_2025_backgrounder.pdf

The Economist. (2010, May 28). A special report on water: For want of a drink. Retrieved from http://www.economist.com/node/16136302/print

Turner, W. M. (2004, April 1). The commoditization and marketing of water. Retrieved from http://www.waterbank.com/Newsletters/nws35.html

Whyte, L. H. \& Romanow, R. J. (1984). Notwithstanding: The making of the constitution (19761982). Toronto, Ontario: Thomson Carswell.

Wood, C. (2005, October). Melting point: How climate change will melt our glaciers, empty the great lakes, force Canada to divert rivers, build dams, and, yes, sell water to the United States. The Walrus Magazine, Retrieved from

http://www.walrusmagazine.com/articles/2005.10-global-warming-future/1/

Ziff, B. (2006). Principles of property law. Toronto, Ontario: Thompson Canada Limited 